\title{
Identification and Analysis of Active Carotenoid Compounds from Entawak Fruit (Artocarpus Anisophyllus)
}

\author{
Gervacia Jenny.R ${ }^{1, a}$, Ratih Indrawati, ${ }^{1, b}$ Jajar Pramata Syari, ${ }^{1, c}$ \\ ${ }^{1}$ Department of TLM Poltekkes Kemenkes Pontianak, Jalan Dr. Sudarso, Pontianak, Indonesia \\ a prodi_d4analis@yahoo.co.id \\ b indrawati.haykal@gmail.com \\ c pramata.syari@gmail.com
}

Abstract - Isolation and identification of active compounds from mentawak fruit (Artocarpus Anisophyllus) used a plant determination test to determine the plant content. Furthermore, the extraction process was carried out to obtain a crude extract of carotenoid pigments by maceration method using n-hexane as solvent. Furthermore, the obtained macerate was carried out by phytochemical tests to determine the content of the active compounds. The TLC test was carried out to confirm the presence of a positive group of compounds on phytochemical screening, and to determine the chromatographic profile of the extract. The identification results showed that the phytochemicals showed that the active compounds contained in macerate were alkaloids, flavonoids, tannins and saponins. The KLT test results obtained an $R f$ value of 0.875 . While the total carotenoid content using a spectrophotometer $\mathrm{UV}$-Vis is $958 \mu \mathrm{g} / \mathrm{ml}$.

Keywords- active compounds, A. Anisophyllus, thin layer chromatography (TLC).

\section{Introduction}

Indonesia is one of the countries that has the largest flora population in the world. Plants contain primary metabolites such as proteins, carbohydrates, and fats which are used by the plant itself for growth and secondary metabolites such as phenolics, flavonoids, terpenoids, steroids, coumarins, and alkaloids which generally have bioactivity capabilities and function as plant protectors from pests disease for the plant itself or the environment.

Carotenoids are produced from isopentenyl pyrophosphate (IPP) components which undergo a gradual process to form various types of carotenoids. There are two groups of carotenoids, namely carotenes and xanthophylls with various types of derivatives. The chemical structure of carotenoid algae is allene, acetylene and acetylated carotenoids [1]. Carotenoids, a yellow to red pigment that is found in all plants and various tissues and involved in photosynthetic auxiliary pigments [2].

Carotenoid pigments in plants have two functions, namely as auxiliary pigments in photosynthesis and as colorants in flowers and fruit. Carotenoids are indispensable for plants and important in the human diet.

Natural dyes are dyes (pigments) obtained from plants, animals, or from mineral sources. These dyes have long been used for food coloring and until now generally their use is considered safer than synthetic dyes. In addition, research on the toxicology of natural dyes is still rather difficult because these dyes generally consist of a mixture with other natural compounds. For example, for natural dyes of plant origin, the shape and levels vary depending on the type of plant, climate, soil, age and other factors [3].

Mentawak is found in almost all districts in Kalimantan such as Sanggau, Bengkayang, Sekadau, Sintang and several other areas in Kalimantan. Easy to cut by hand and reveal bright orange red flesh between the 'dami'. Delicious sweet fruit taste, fragrant aroma, soft fruit flesh texture with hard seeds. Mentawa fruit is very liked by the people of the interior of West Kalimantan. They prefer to consume Mentawak fruit that is half-ripe rather than ripe fruit. Its natural habitat is tropical rain forest, the conversion of its habitat to monoculture cultivation has the potential to reduce the increasingly rare Mentawaian population [4].

Research that has been conducted on phytochemical studies of several species of Artocarpus shows that this species contains secondary metabolites such as terpenoids and flavonoids (stilbenoids, arylbenzofurans, neolignans, Diels-Alder adducts). The flavonoid group is a compound 
that has been widely studied from the Artocarpus plant [5]. It is estimated that flavonoids isolated from leaves and stems have the potential to be developed as antimicrobial agents [6].

The release of carotenoid compounds in mentawak fruit (A. anisophyllus), can be through an extraction process with several methods ranging from conventional to modern methods. These methods have their respective advantages and disadvantages. Therefore, with the development of the times, there are effective and efficient extraction methods for extracting pigments from materials [7]. The purpose of an extraction process is to obtain an unknown active ingredient, obtain a known active ingredient, obtain a group of compounds with similar structures, obtain all secondary metabolites from a plant part with a certain species, and identify all secondary metabolites contained in an extract living things as chemical markers or metabolic studies [2].

\section{Research Method}

The research design in this study is an experimental research. This research was conducted at the Biology Laboratory, Faculty of Mathematics and Natural Sciences, Tanjung Pura University, Pontianak. The population of this study was the fruit of the Entawak which was obtained in the Sekayam District, Sanggau Regency, West Kalimantan. The sample in this study was the extract of the Entawak fruit.

\section{A. Plant Determination}

Determination is to compare a plant with another plant that has been previously known (matched or equated), so as to avoid mistakes in collecting the material to be studied. Entawak fruit (A. anisophyllus) obtained from Sekayam District, Sanggau Regency, West Kalimantan. Plants to be tested for determination must be complete with roots, stems, leaves, and flowers. The Entawak plant (Artocarpus anisophyllus) used in this study was determined at the Biology Laboratory, Faculty of Mathematics and Natural Sciences, Tanjung Pura University.

\section{B. Entawak Fruit Maceration Process}

Entawak fruit extraction was carried out by maceration method. Dried samples of Entawak fruit (A. anisophyllus) were cut into small pieces and weighed as much as 100 grams and then macerated (until the entire tissue was submerged) with n-hexane p.a. The extraction process was stirred for 15 minutes and then allowed to stand for $3 \times 24$ hours at room temperature. Extraction was also carried out by varying the $\mathrm{pH}$ from 2-10 with the addition of citric acid for acidic conditions and sodium hydroxide solution for alkaline conditions. The filtrate obtained was then filtered and the solvent was reevaporated using a Rotary Evaporator to obtain data on the crude extract of Entawak fruit [8].

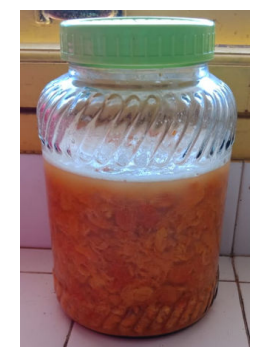

(a)

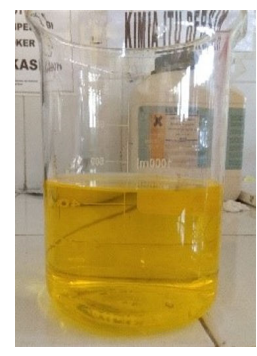

(b)
Figure 1. (a). Maceration Process, (b). Maceration Result

\section{Phytochemical Test}

a). Identification of flavonoids

1 gram of sample extract was put into a test tube and then concentrated $\mathrm{HCl}$ was added and then heated for 15 minutes on a water bath. If a red or yellow color is formed, it means that it is positive for flavonoids (flavones, chalcones and aurons).

\section{b). Identification of Alkaloids}

2 grams of the sample extract was put into a test tube dripped with $5 \mathrm{~mL}$ of $2 \mathrm{~N} \mathrm{HCl}$ heated then cooled and then divided into 3 test tubes, $1 \mathrm{~mL}$ each. Each tube is added with each reagent. On the addition of Mayer's reagent, it is positive for alkaloids if it forms a white or yellow precipitate. On the addition of Wagner's reagent, it is positive for alkaloids if a brown precipitate is formed. On the addition of Dragendrof reagent, it contains alkaloids if an orange precipitate is formed.

\section{c). Identification of Saponins}

1 gram of the extract was put into a test tube, $10 \mathrm{~mL}$ of hot water was added, cooled and then shaken vigorously for 10 seconds. It was positive for saponins if $1-10 \mathrm{~cm}$ high foam was formed, not less than 10 minutes and with the addition of 1 drop of $2 \mathrm{~N} \mathrm{HCl}$, the foam did not disappear.

\section{d). Identification of Tannins}

1 gram of extract is put into a test tube, $10 \mathrm{~mL}$ of hot water is added and then boiled for 5 minutes then the filtrate is added 3-4 drops $\mathrm{FeCl}_{3}$, if it is blue green (greenblack) it means that it is positive for catechol tannins, 
while if it is blue black it means positive for pyrogalol tannins.

\section{e). Identification of Terpenoids and Steroids}

2 grams of sample extract was put in a test tube, then added with $2 \mathrm{~mL}$ of ethyl acetate and shaken. The ethyl acetate layer was taken and then dropped on a drip plate and allowed to dry. After drying, 2 drops of anhydrous acetic acid and 1 drop of concentrated sulfuric acid were added. If a red or yellow color is formed, it means that it is positive for terpenoids. If a green color is formed, it means steroid positive.

\section{TLC test}

The extracted pigment was dissolved in acetone. A total of 101 of the solution was spotted on the TLC plate. The sample was then eluted using chloroform and ethyl acetate as mobile phase in a ratio of 7:3. a pattern of pigment separation will be formed and measured. The measurement results are then calculated the $\mathrm{Rf}$ value using the following formula [9]:

$$
R f=\frac{\text { the distance througt by the compound }}{\text { the distance througt by the solvent }}
$$

\section{E. Analysis of the carotenoid content of Entawak fruit (A. Anisophyllus)}

The concentrated extract was added with a buffer solution of $\mathrm{pH} 1$ and $\mathrm{pH}$ 4.5. The solution was then measured its absorbance at a wavelength of $425 \mathrm{~nm}$ using a UV-Vis spectrophotometer to determine the quantity of carotenoids in the extract [9].

\section{Results and Discussion}

\section{A. Plant Determination Test}

Based on the results of the determination test, the data can be obtained as shown in table 1 .

Table 1. Plant Determination Test

\begin{tabular}{|c|c|}
\hline & Classification \\
\hline Kingdom & Plantae \\
\hline Divisi & Tracheophyta \\
\hline Kelas & Magnoliopsida (dicots) \\
\hline Ordo & Rosales \\
\hline Famili & Moraceae \\
\hline Genus & Artocarpus \\
\hline Spesies & A. anysophyllus Miq \\
\hline Region Name & Entawak \\
\hline
\end{tabular}

Based on table 1, it was found that the entawak fruit used as the sample came from the entawak plant.

\section{B. Phytochemical Test}

Phytochemical test results are presented in table 2.

Table 2. Phytochemical Test

\begin{tabular}{|l|c|}
\hline \multicolumn{1}{|c|}{ Measurement } & Measurement Result \\
\hline Alkaloid & + (Positive) \\
\hline Flavonoid & + (Positive) \\
\hline Steroid/Terpenoid & - (Negative) \\
\hline Fenolik & - (Negative) \\
\hline Tanin & + (Positive) \\
\hline Saponin & + (Positive) \\
\hline
\end{tabular}

Based on the results of phytochemical tests, it was obtained that the n-hexane extract of Entawak fruit contains active compounds of alkaloids, flavonoids, tannins and saponins. The results of the phytochemical test can be seen in Figure 2.

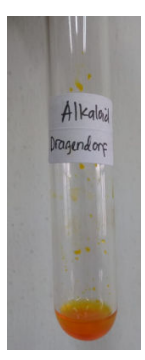

(a)

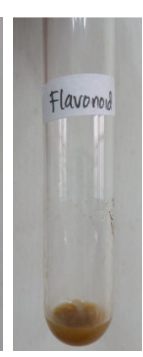

(b)

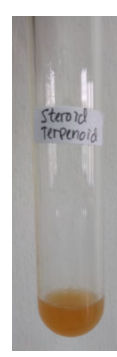

(c)

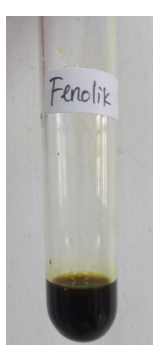

(d)

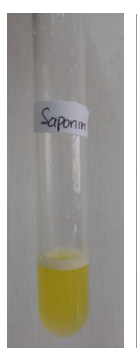

(e)

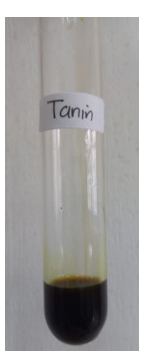

(f)
Figure 2. Phytochemical Test Results of Entawak Fruit Extract (a) Alkaloid Test with Dragendrof reagent, (b) Flavonoid Test,

(c) Steroid/terpenoid Test, (d) Phenolic Test, (e) Saponin Test and (f) Tannin Test.

\section{Thin Layer Chromatography (TLC) Test}

The results of the analysis of the thin layer chromatography test are presented in Table 3.

Table 3. TLC Test Results

\begin{tabular}{|c|c|c|}
\hline Stain & $\begin{array}{c}\text { Rf } \\
\text { Value }\end{array}$ & $\begin{array}{c}\text { Stain color after 366 nm UV } \\
\text { irradiation }\end{array}$ \\
\hline 1 & 0,75 & Light Green \\
\hline 2 & 0,875 & Blue \\
\hline 3 & 0,95 & Pink \\
\hline
\end{tabular}

The results of the test using methanol eluent: ethyl acetate (4:6) formed 3 spots with an $\mathrm{Rf}$ value of 0.75 in a row; 0.875 ; and 0.95 . Spots that are suspected to be alkaloid compounds are at $\mathrm{Rf} 0.75$ and 0.875 . This is based on research by Mufadal [10] where the eluent used was ethyl acetate: methanol: water $(6: 4: 2)$ indicating the 
presence of alkaloid compounds shown from under a 365 nm UV lamp producing a bright blue color and with an Rf value of 0.15 and 0.78 [10]. The appearance of stains with $\mathrm{Rf} 0.875$ was blue on observation and light green with UV $366 \mathrm{~nm}$ confirmed the presence of alkaloids in the extract of the Entawak fruit [11].

\section{UV-Vis Spectrophotometer Test}

Determination of total carotenoids was carried out by measuring the sample or comparator dissolved in a nonpolar solvent at a wavelength of $425 \mathrm{~nm}$ and in a betacarotene comparator. Determination of carotenoid levels using beta carotene as a standard solution because it has the ability to reduce free radicals due to the presence of conjugated double bonds.

\section{E. Determination of Total Carotenoids in Extract}

a). Preparation of -carotene . comparison solution

Weighed $50 \mathrm{mg}$ of -carotene and dissolved in $50 \mathrm{ml}$ of n-hexane p.a (stock solution $1000 \mathrm{ppm}$ ). Then made dilutions with concentrations of 3, 5, 6, 9 and $12 \mathrm{ppm}$ in $10 \mathrm{ml}$, respectively.

\section{b). Maximum wavelength measurement}

One concentration was taken from the comparison solution $(80 \mathrm{ppm})$ and then the absorption was measured using a spectrophotometer UV-vis. The wavelength that shows the highest absorption is used as the maximum wavelength of $425 \mathrm{~nm}$.

\section{c). Making comparison curve}

A comparison curve was made by connecting the concentration of the reference solution with the absorption results obtained from measurements using a spectrophotometer UV-VIS at a wavelength of $425 \mathrm{~nm}$.

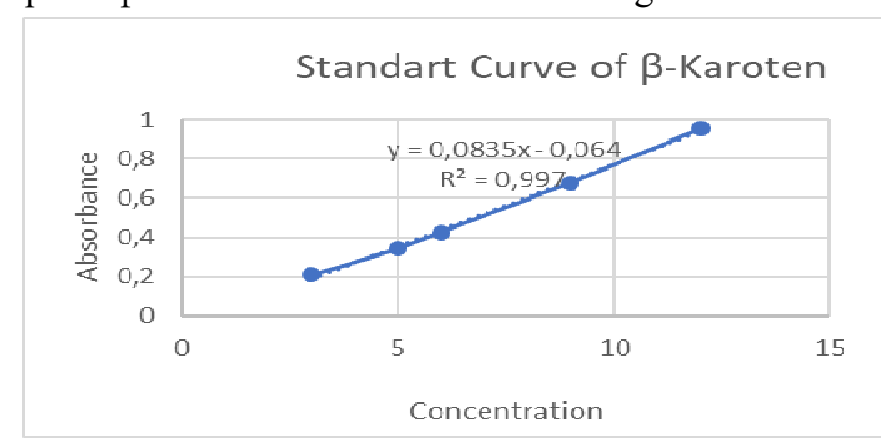

Figure 3. Standard Curve

From the standard curve, the linear equation $\mathrm{Y}=$ $0.08354 \mathrm{x}-0.06398$ is obtained and the correlation coefficient $(\mathrm{R} 2)=0.997$ these results indicate that there is a linear relationship between concentration and absorbance. The value (r) which is close to one indicates that the regression equation is linear.

\section{d). Sample rate measurement}

A total of $0.010 \mathrm{~g}(10 \mathrm{mg})$ of the sample was dissolved in n-hexane p.a then made up to $5 \mathrm{ml}$ in volume. $2 \mathrm{ml}$ was taken to measure the absorption at a wavelength of $425 \mathrm{~nm}$. Measurements were carried out in triples. Total carotenoid content was calculated into the equation of the linear regression line.

Table 4. Sample Rate Measurement

\begin{tabular}{|c|c|}
\hline Sample Absorbance & Rate Measurement \\
\hline 0.274 & $958 \mu \mathrm{g} / \mathrm{ml}$ \\
\hline
\end{tabular}

The absorbance of the sample obtained was then entered into a straight-line equation so that the total carotenoid content of the extract was $958 \mu \mathrm{g} / \mathrm{ml}$.

\section{Conclusion}

Based on the research that has been done, it can be concluded that Entawak fruit extract contains active compounds of flavonoids, alkaloids, tannins and saponins. Entawak fruit extract has a total carotenoid content of $958 \mu \mathrm{g} / \mathrm{ml}$.

\section{Acknowledgment}

We would like to thank the Director of Poltekkes, Ministry of Health Pontianak, Head of the Pontianak Health Analyst Department and fellow lecturers at the Pontianak Health Analyst Department who have provided guidance, assistance, support and motivation in writing this journal and thank the entire team of enumerators who have helped completion of this research.

\section{References}

[1] W. Merdekawati, F. F. Karwur, and A. B. Susanto, "Karotenoid Pada Algae: Kajian Tentang Biosintesis, Distribusi Serta Fungsi Karotenoid", (Carotenoids in Algae: A Study on the Biosynthesis, Distribution and Function of Carotenoids), Bioma, vol. 13, no. 1, pp. 23-32, 2017, doi: 10.21009/bioma13(1).3.

[2] L. H. Endarini, Farmakognisi dan Fitokimia (Pharmacognition and Phytochemistry), 1st ed. Jakarta: Pusdik SDM Kesehatan Kementrian Kesehatan RI, 2016.

[3] S. Koswara, "Pewarna Alami: Produksi dan Pengolahannya", (Natural Dyes: Production and Processing) 2009, [Online]. Available:

http://tekpan.unimus.ac.id/wp-content/uploads/2013/07/Pewarna Alami.pdf. 
[4] BPTP and (Badan Penelitian Dan Pengembangan Pertanian) Kementrian Pertanian Pertanian Kal-Bar, "Penelitian Mentawak (Research on Artocarpus Anisophyllus)." 2019.

[5] A. Hakim, "Diversity of secondary metabolites from Genus Artocarpus ( Moraceae )," J. Nusant. Biosci., vol. 2, no. 3, pp. 146-156, 2010, doi: 10.13057/nusbiosci/n020307.

[6] H. Chadburn, "Artocarpus Anisophyllus," IUCN Red List Threat. Species ${ }^{T M}$, vol. 8235, pp. 301-303, 2018, doi: 10.1007/978-94-007-2534-8_38.

[7] H. S. Maleta, R. Indrawati, L. Limantara, T. Hardo, and P. Brotosudarmo, "Ragam Metode Ekstraksi Karotenoid dari Sumber Tumbuhan dalam Dekade Terakhir (Telaah Literatur)", (Various Carotenoid Extraction Methods from Sources of Plants in Recent Decade (Review Paper)," J. Rekayasa Kim. dan Lingkung., vol. 13, no. 1, 2018.

[8] S. dkk Allen, "Process For Extracting Carotenoids From Fruit and Vegetables Processing Waste," US 2004O131748A1, vol. 1, no. 19, 2004.
[9] J. Ngginak, A. Rafael, D. Amalo, S. T. Nge, and C. L. Sandra Bisilissin, "Analisis Kandungan Senyawa $\beta$-Karoten Pada Buah Enau (Arenga piñata) Dari Desa Baumata", (Analysis of the Content of -Carotene Compounds in Enau Fruit (Arenga piñata) from Baumata Village), Jambura Edu Biosf. J., vol. 2, no. 1, pp. 2656-0526, 2020, [Online]. Available: http://ejurnal.ung.ac.id/index.php/edubiosfer/article/view/2717.

[10] Mufadal, "Isolasi Senyawa Alkaloid dari Alga Merah menggunakan KLT serta serta analisa dengan Spektrofotometer uv-vis dan FTIR", (Isolation of Alkaloid Compounds from Red Algae using TLC and analysis with uv-vis spectrophotometer and FTIR), 2015.

[11] M. Mulana, Profil Kromatografi Lapis Tipis (KLT) Ekstrak Daun Bidara Arab ( Ziiphus spina cristi.L) Berdasarkan Variasi Pelarut", (Thin Layer Chromatography (TLC) Profile of Arabic Bidara Leaf Extract (Ziiphus spina cristi.L) Based on Solvent Variations),

2018 ,

p.

2018. 